\title{
An analysis of Physical and chemical parameters in some rivers in Yobe state
}

\author{
Muhammad Umar Mustapha \\ Desert Research Monitoring and Control Center Yobe State University P.M.B 1144 Damaturu \\ umardrc@gmail.com
}

\begin{abstract}
Water samples from six different areas in Yobe state will be physically, chemically and bacteriologically analyzed in order to ascertain the levels of pollution influence, Temperature, total dissolved solid(TDS), electrical conductivity, turbidity, colour and PH will be determined. Also to determine were chloride, calcium, manganese, sulphate, nitrate, fluoride,magnesium, iron, chromium (hexavalent), calcium, total hardness, and total coliform and escheridia coli. The concentration of pollution indicators ranged from 26.2 to 31.2 oc for temperature, 0.06 to $0.23 \mathrm{~ms} / \mathrm{cm}$ for electrical conductivity, 0.03 to $0.11 \mathrm{mg} / \mathrm{l} \mathrm{for} \mathrm{total}$ dissolve solid, 1.0 to 461 ofTU for turbidity, 12.0 to 550.0 ptco for colour, 0.17 to $3.30 \mathrm{mg} / \mathrm{l}$ for iron, 0.01 to $0.62 \mathrm{mg} / \mathrm{l}$ for chromium (hexavalent), 0.2 to $14.2 \mathrm{mg} / \mathrm{l}$ for manganese, 2.0 to $75 \mathrm{mg} / \mathrm{l}$ for sulphate, 1.6 to 35.8 $\mathrm{mg} / \mathrm{l}$ for nitrate, 0.00 to $0.04 \mathrm{mg} / \mathrm{l}$ for fluoride, 0.3 to $24.5 \mathrm{mg} / \mathrm{l}$ for chloride, 0.668 to $0.668 \mathrm{mg} / \mathrm{l} \mathrm{for} \mathrm{calcium}$, 0.160 to $0.290 \mathrm{mg} / \mathrm{l}$ for magnesium, 0.828 to $0.958 \mathrm{mg} / \mathrm{l}$ for total hardness, 6.0 to 7.0 for $\mathrm{pH}$.
\end{abstract}

Key words: River water, quality, anion cat ion

\section{Introduction}

Water is a finite resource that is very essential for the human existence, without any doubt, inadequate quantity and quality of water have serious impact on sustainable development. In developing countries, most of which have huge debt burdens, population explosion and moderate to rapid urbanization, people have little or no option but to accept water sources of doubtful quality, due to lack of better alternative sources or due to economic and technological constraints to treat the available water adequately before use (Calamari and Naeve, 1994; Aina and Adedipe, 1996). The scarcity of clean water and pollution of fresh water has therefore led to a situation in which one-fifth of the urban dwellers in developing countries and three quarters of their rural dwelling population do not have access to reasonably safe water supplies (Lloyd and Helmer, 1992). Drinking water that is safe and aesthetically acceptable is a matter of higher priority to National Authority for food and Drugs Administration (NAFDAC). Drinking water is satisfied fit for human comsuption by (NAFDAC) is expected to meet the World Health Organization (WHO) standard to be free from physical, chemical substance and micro-organism in the amount that could not be hazardous to health.

Assessment of water is not only for suitability for human consumption but also in relation to its agricultural, industrial, recreational, commercial uses and its ability to sustain aquatic life.

Water quality monitoring is therefore a fundamental tool in the management of freshwater resources. To underpin its importance, World Health Organization (WHO), United Nations Environment Programme (UNEP), United Nations Educational, Scientific and Cultural Organization (UNESCO) and World Meteorological Organization (WMO) launched in 1977, a water monitoring programme to collect detailed information on the quality of global ground and surface water.

Water plays another role for man. It carries away his wastes. As the most abundant liquid on earth, water runs steadily to sea along a vast network of rivers. It is a receptacle for sewage, it can be used to rinse away grime or toxic chemicals; or remove waste heat from boilers (Tchobanoglous 1985).

Scientist discovered that there are 326 million cubic miles of water in the world, each one representing more than one trillion gallons. water is the major constituents of living matter and forms 50 to $90 \%$ of the weight of living organism's protoplasm. Water was also referred to as the most abundant chemical compounds; that occurs in three states: Solid (ice or snow), liquid (water) and gas (water vapour or stream). (Wilmot 1997).

\section{Materials And Method}

Materials

The material includes;

1. Spectrophotometer $(\mathrm{DR} / 2000) \mathrm{HACH}$

2. Conductivity / TDS Meter

3. Incubator

4. Colony counter

5. Microscope 


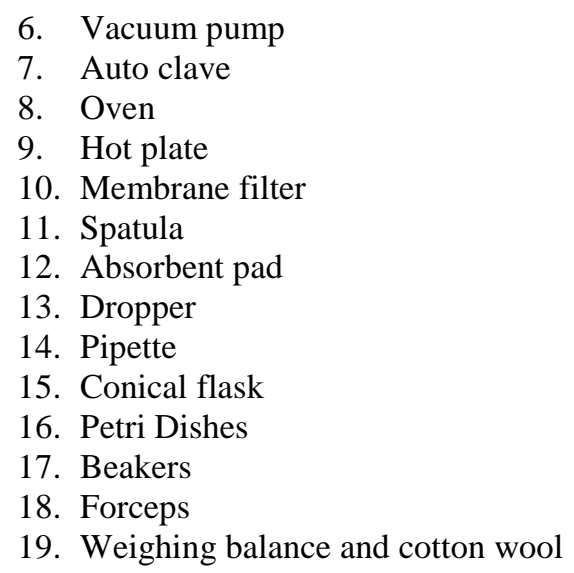

Reagents

1. Mac Conkey agar

2. Distilled water

3. Ethanol

4. Ferro Ver iron reagent powder pillow

5. Chroma Ver -3 - reagent powder pillow

6. Buffer powder pillow, citrate type

7. Sodium periodate powder pillow

8. Sulfa Ver -4 - sulfate reagent powder pillow

9. SPADNS Reagent

10. Mercuric Thiocynate solution

11. Ferric ion solution

12. Calcium and magnesium indicator solution

13. Alkali solution

14. EDTA solution

15. $\mathrm{pH}$ Litmus paper

Sample Collection

The water sample will be collected in a sterilized container from six different rivers for the analysis. LOCATIONOF SAMPLE COLLECTION

1. Sample A from Nguru river

2. Sample B from Katarko river

3. Sample C form Geidam river

4. Sample D from Gashua river

5. Sample E from Dagona river

6. Sample F from Ngaji river

Method

Analysis of water sample using Atomic absorption Spectrometer (AAS - DR 2000) or U-V/visible. About (13) parameters will be analyzed using the spectrometer. The parameters includes turbidity, colour, $\mathrm{PH}$, iron, chromium (hexavalent), manganese, sulfate, nitrate, fluoride, chloride, calcium, magnesium, and total hardness respectively. While the total dissolved solid, electrical conductivity and temperature will be analyzed using conductivity/TDS meter as well.

\section{Results And Discussion}

The results under physical parameters were compared with the World Health Organization Standard in order to show the quality of the water from different sample collection areas in Yobe state. Considering the temperature of the samples at the period of the study falls within the range of $26.2^{\circ} \mathrm{C}$ to $31.2^{\circ} \mathrm{C}$, this is because the nature of sahelian climatic condition of Yobe state.

In the analysis of electrical conductivity, which is a measurement of water capacity for converting electrical current and is directly related to the concentration of ion in the water, the range falls within the limits of World Health Organization Standard values. The results of total dissolved solid, was within the limits of WHO standard values. The turbidity which is mostly caused by the presence of suspended particles such as clay, silk, finely divided organic and in organic matters which makes the water to become muddy. It is also caused by 
industrial waste product and the growth of algae. Therefore, the turbidity of samples A, B, C and D as well as the colour of sample A, B, C and D exceeded the WHO standard values, except for sample E where the turbidity and colour respectively fall below the acceptable values. Colouration of water is caused by the presence of some metallic salts, organic matters and other dissolved material present. The chemical parameters were also compared with the standard values of (WHO).

Iron is one of the major components of the earth's crust occurs naturally in some ground water. The presence of the iron in the sample B, C and D were above the acceptable level of WHO. These values could cause poisoning in children and adults and affect the normal regulatory mechanism not to operate effectively. The chromium (hexavalent) in sample B, C and D exceeded the standard values of WHO and could cause cancer, inflammation of kidney and liver where as sample A and $\mathrm{E}$ have low level of chromium and could cause irritation of gastro intestinal mucosa to occur. The presence of manganese in sample A, B, C, D and E where within the range of WHO standard, while sample A, B, C, D and E have sulphate, nitrate, fluoride, chloride, calcium and magnesium concentration below the WHO standard except for total hardness which cause corrosion of pipes.

The PH value of sample B, C, D and E all falls within the acceptable values except sample A which has $\mathrm{PH}$ of 6.0 which is below the WHO standard.

\section{Conclusion}

The analysis of water sample from various locations in Yobe state, shows that the physicochemical parameters of most of the water sample collected were contrary to the value set by World Health Organization, therefore the result from this study clearly demonstrate that the water quality from rivers in Yobe state are unfit for human consumption there is urgent need to develop some form of local treatment to purify the waters for people of yobe state and other places in Nigeria. This will help go a long way to ensure that the Millennium Development Goals (MDGs) are achieved by 2015.

\section{References}

[1]. Adigun, B. A.(2005) water quality management in aquaculture and freshwater zooplankton production for use in fish hatcheries vol

[2]. Anna, E. O. A.; Adedipe, N. O., (1996).Water quality monitoring and environmental status in Nigeria.FEPA Monograph 6, FEPA, Abuja, Nigeria, 239.

[3]. British Geological Survey.British. Pp. 7-8

[4]. Calamari, D.; Naeve, H., (1994). Review of pollution in the African aquatic environment.

[5]. Chapman, D., (1996). Water quality assessments: A guide to the use of biota, sediments andwater in environmental monitoring 2nd. Ed. UNESCO, Worl Health Organization, United Nations Environment Programme, London.

[6]. DFID, (1999). A Simple Methodology for Water Quality Monitoring. G. R. Pearce, M. R.

[7]. DWAF, (1995). South African water quality management series.Procedures to Assess effluent Discharge Impacts.WRC Report No.TT 64/94. Department of Water Affairs and Forestry and Water Research Commission, Pretoria.

[8]. DWAF, (1996a). South African Water Quality Guidelines.Domestic Uses.2nd. Ed.

[9]. Department of Water Affairs and Forestry, Pretoria, Vol. 1.

[10]. DWAF, (1996b). South African Water Quality Guidelines, (Volume 2), Recreational

[11]. Water Use 2nd Ed.). Department of DWAF; WRC, (1995).South African water quality management series. Procedures to Assess Effluent

[12]. Discharge Impacts. WRC Report No.TT 64/94. Department of Water Affairs Forestry and Water Research Commission, Pretoria. Water Affairs and Forestry, Pretoria.

[13]. DWAF, (1996c).South African Water Quality Guidelines, Aquatic ecosystems (1st. Ed.).

[14]. Department of Water Affairs and Forestry, Pretoria, Vol. 7.

[15]. DWAF, (1996d). South African Water Quality Guidelines, Agricultural water use irrigation (2nd. Ed.). 4, Department of Water Affairs and Forestry Pretoria.RSA.

[16]. Hofkes; E.H (1988): small Community water Supplies, $5^{\text {th }}$ ed. Galliards Ltd. Great Britain Pp43

[17]. Landenika; O (1988): "Borehole Construction and Maintenance" Paper presented at an intensive training workshop at Lagos Airport, Ikeja Lagos.

[18]. National Agency for Food and drugs Administration and Control (NAFDAC) (2004): Quality Parameter for Package Water IPAN New. Pp6

[19]. Niwasa (2002): Water front vol. I published by Eaux well Nigeria limited. Nigeria. Pp. 4, 34.

[20]. Gray, A.V. 1989. Case study on water quality modelling of Dianchi lake, Yunnan province, southwest China.Water Sci. Technol. 40:35-43.

[21]. Gupta, G. K., Shukle, R., (2006). Physiochemical and Bacteriological Quality in Various Sources of Drinking Water from Auriya District (UP) Industrial Area.Pollution Research, 23 (4): 205-209.

[22]. Jaji, M. O.; Bamgbose, O.; Odukoya, O. O.; Arowlo, T. A., (2007).Water quality assessment of Ogun River, south west Nigeria. Environ. Monit. Assess., 133 (1-3), 447-482 (36 pages)

[23]. Katsuro, A., Yashiko, K., Yoshinnori, S., Takashi, T., and Hayao, S., 2004. Heavy -metal Distribution in River Waters and sediment a "firefly village", Shikou, Japan: Application of multivariate Analysis. analytical science, 20, 79-84.

[24]. Lloyd, B.; Helmer, R., (1992).Surveillance of drinking water quality in rural area. Longman Scientific and Technical Publication.New York, Wiley.34-56.

[25]. Lowel and Thompson F., 1992.Biodiversity of vibrios.Microbiol. Mol. Biol. Rev., 68: 403-431.

[26]. Miller and siemmens 2003 Anal. Chem., 31, 426-428.

[27]. Morrison, G.; Fatoki, O. S.; Persson, L.; Ekberg, A., (2001). Assessment of the impact Keiskammahoek Sewage Treatment Plant on the Keiskamma

[28]. River-pH, electrical conductivity, oxygen demanding substance (COD) and nutrients. Water SA., 27 (4), $475-480$ (6 pages). 
[29]. Ogunfowokan, A. O.; Okoh, E. K.; Adenuga, A. A.; Asubiojo, O. I., (2005). Assessment of the impact of point source pollution from a University sewage treatment oxidation pond on the receiving stream-a preliminary study.J. App. Sci., 6 (1), 36-43 (7 pages).

[30]. Okoh, A. I., (2007). Wastewater treatment plants as a source of microbial pathogens in the receiving watershed. Afr. J. Biotech. 6 (25),2932-2944 (13 pages).

[31]. Okoye, P. A. C., Enemuoh, R. E. and Ogunjiofor, J. C., 2002.Traces of heavy metals in Marine crabs. J. Chem. Soc. Nigeria, vol. 27 (1) $76-77$

[32]. Pandey, (2003).Trends in eutrophication research and control.Hydrol.Proc., 10 (2), 131-295 (165 pages).

[33]. PatilDilip B, TijareRajendra V (DeptChem, GovtSciColl, Gadchiroli 442605). Investigation of pollution mystery of suspected carcinogen $\mathrm{Cr}$ (VI) and its control.

[34]. modeling in a layered siol profile using fuzzy set theory. J. Hydroinform., 1: 127-138.

[35]. Singh RP, Mathur P (Dept Environ Std, MDS Univ, Ajmer 305 009). Investigation of variations in physico-chemical characteristics of a fresh water reservoir of Ajmer city,

[36]. Rajasthan.Indian J Environ Sci, 9(1)(2005), 57-61 [15 Ref].

[37]. UNEP, (1993). Environmental data report (93/94). United Nation Environment Programme, Blackwell, Oxford, UK, 63-105.

[38]. UNESCO, Water Quality surveys.A Guide for the collection and interpretation of Water Quality Data.

[39]. Watson, C. and Cichra; C. E. (2006) Department of fisheries and Aquatic Sciences florida cooperatives extention services. Institute of food and Agriculture sciences, University of florida. First edition; June 1990, second edition, 2006.

[40]. WHO, (1984).Guideline for Drinking Water Quality Recommendation. World Health

[41]. Organization, Geneva, Vol. 1, 130.

[42]. WHO, (1989).Health guidelines for use of wastewater in agriculture and aquaculture. WorldHealth Organization.Technical Report Series 778. Geneva, Switzerland.

[43]. World Health Organization (1997): guidelines for drinking water quality vol.3. Published by C.B.S. India. Pp.4

[44]. WHO, (2002). Water and health in Europe: A joint report from the European Environment Agency and the WHO Regional Office for Europe. World Health Organization, WHO Regional Publications, European Series No. 93.

[45]. WRC, (2000).National eutrophication monitoring programme. Water Research Commission Spectrophotometer hand Book, DR/2000. Instrument manual. HACH Company.

Table i. Physical parameters of water samples collected from different areas in Yobe state compared with (WHO) standard of physical parameters (1984).

\begin{tabular}{|l|l|l|l|l|l|l|l|}
\hline Parameters & $\begin{array}{l}\text { Sample A } \\
\text { Nguru }\end{array}$ & $\begin{array}{l}\text { Sample B } \\
\text { Katarko }\end{array}$ & $\begin{array}{l}\text { Sample C } \\
\text { Geidam }\end{array}$ & $\begin{array}{l}\text { Sample D } \\
\text { Gashua }\end{array}$ & $\begin{array}{l}\text { Sample } \\
\text { Ngaji }\end{array}$ & $\begin{array}{l}\text { EHO) } \\
\text { Standard }\end{array}$ \\
\hline $\begin{array}{l}\text { Temprature } \\
\left({ }^{\circ} \text { C) }\right.\end{array}$ & 31.2 & 28.3 & 27.7 & 26.9 & 26.2 & \\
\hline $\begin{array}{l}\text { Electrical } \\
\begin{array}{l}\text { Conductivity } \\
(\mathrm{mS} / \mathrm{cm})\end{array}\end{array}$ & 0.23 & 0.07 & 0.06 & 0.09 & 0.05 & 14.0 \\
\hline TDS (mg/l) & 0.11 & 0.04 & 0.03 & 0.04 & 0.04 & 1,500 \\
\hline $\begin{array}{l}\text { Turbidity } \\
(\text { FTU) }\end{array}$ & 10.0 & 101.0 & 461.0 & 83.0 & 1.0 & 5.0 \\
\hline $\begin{array}{l}\text { Colour } \\
\text { co) }\end{array}$ & 36.0 & 422.0 & 550.0 & 446.0 & 12.0 & 15.0 \\
\hline
\end{tabular}

Table ii

Table ii, shows the World Health Organization standard of Physical Parameters (1984).

\begin{tabular}{|l|l|c|}
\hline Parameters & Acceptable Level & Effect Above/Below Effect \\
\hline Temperature $\left({ }^{\circ} \mathrm{C}\right)$ & \multicolumn{1}{|c|}{--} & -- \\
\hline Electrical conductivity (mS/cm) & 14.0 & -- \\
\hline Total Dissolve Solid (mg/l) & 1500 & -- \\
\hline Turbidity (FTU) & 5.0 & VISUAL \\
\hline Colour (Pt co) & 15.0 & VISUAL \\
\hline
\end{tabular}

Table iii. Shows the chemical parameters of water samples from different areas in Yobe state

\begin{tabular}{|c|c|c|c|c|c|c|}
\hline $\begin{array}{l}\text { Parameters } \\
(\mathrm{Mg} / \mathrm{L})\end{array}$ & $\begin{array}{ll}\text { Sample } & \text { A } \\
\text { Nguru } & \end{array}$ & $\begin{array}{ll}\text { Sample } & \text { B } \\
\text { Katarko } & \end{array}$ & $\begin{array}{ll}\text { Sample } & \mathrm{C} \\
\text { Geidam } & \end{array}$ & $\begin{array}{ll}\text { Sample } & \text { D } \\
\text { Gashua } & \end{array}$ & $\begin{array}{ll}\text { Sample } & \text { E } \\
\text { Ngaji } & \end{array}$ & $\begin{array}{l}\text { WHO }) \\
\text { Standard }\end{array}$ \\
\hline Iron & 0.17 & 3.30 & 2.38 & 2.65 & 0.65 & 1.0 \\
\hline $\begin{array}{l}\text { Chromium } \\
\text { (Hexavalent) }\end{array}$ & 0.03 & 0.13 & 0.62 & 0.09 & 0.01 & 0.05 \\
\hline Manganese & 0.02 & 2.2 & 14.2 & 1.3 & 0.5 & 0.05 \\
\hline Sulphate & 29.0 & 29.0 & 75.0 & 15.0 & 2.0 & 400.0 \\
\hline Nitrate & 35.8 & 2.0 & 6.7 & 4.0 & 1.6 & 50.0 \\
\hline Fluoride & 0.00 & 0.00 & 0.00 & 0.00 & 0.04 & 1.5 \\
\hline Chloride & 6.2 & 8.8 & 24.5 & 2.5 & 0.3 & 250.0 \\
\hline Calcium & 0.668 & 0.668 & 0.668 & 0.668 & 0.668 & 250.0 \\
\hline Magnesium & 0.290 & 0.220 & 0.160 & 0.290 & 0.230 & 50.0 \\
\hline Total Hardness & 0.958 & 0.888 & 0.828 & 0.958 & 0.898 & 60.0 \\
\hline $\mathrm{PH}$ & 6.0 & 7.0 & 7.0 & 7.0 & 7.0 & $6.5-8.5$ \\
\hline
\end{tabular}


Table iv. The Table below shows the World Health Organization standard of chemical parameters (1984)

\begin{tabular}{|c|c|c|c|}
\hline Parameters $(\mathrm{Mg} / \mathrm{L})$ & Acceptable Level Mg/L & Effect Below Level & Effect Above Level \\
\hline Iron & 1.0 & $\begin{array}{l}\text { Reduces production of blood, } \\
\text { but no adverse effect on human }\end{array}$ & $\begin{array}{l}\text { Poisoning in children, in adults, } \\
\text { normal regulatory mechanism } \\
\text { do not operate effectively }\end{array}$ \\
\hline $\begin{array}{l}\text { Chromium } \\
\text { (Hexavalent) }\end{array}$ & 0.05 & $\begin{array}{l}\text { Irritation of gastro intestinal } \\
\text { mucosa }\end{array}$ & $\begin{array}{l}\text { Cancer, inflammation of kidney } \\
\text { and liver, bone and tissue death } \\
\text { and death in human }\end{array}$ \\
\hline Manganese & 0.05 & $\begin{array}{l}\text { Anaemia and bone changes in } \\
\text { children }\end{array}$ & $\begin{array}{l}\text { No apparent adverse effect on } \\
\text { man, }\end{array}$ \\
\hline Sulphate & 400.0 & Physiologically harmless & $\begin{array}{l}\text { corrosion in metals and causes } \\
\text { purging in human }\end{array}$ \\
\hline Nitrate & 50.0 & No effect on health & $\begin{array}{l}\text { Blood disease and death in } \\
\text { infant, liver and kidney } \\
\text { inflammation in children }\end{array}$ \\
\hline Fluoride & 1.5 & No effect on health & $\begin{array}{l}\text { Causes tooth decay in both child } \\
\text { and adult, also causes kidney } \\
\text { disease, cancer. }\end{array}$ \\
\hline Chloride & 250.0 & & \\
\hline Calcium & 250.0 & & No adverse Health effect \\
\hline Magnesium & 50.0 & & No adverse Health effect \\
\hline Total Hardness & 60.0 & $\begin{array}{l}\text { Corrosion of pipes, causes } \\
\text { heavy metals to be found in } \\
\text { water, deposit crust on kitchen } \\
\text { utensils and domestic } \\
\text { disadvantage }\end{array}$ & No adverse Health effect \\
\hline $\mathrm{PH}$ & $6.5-8.5$ & & \\
\hline
\end{tabular}

